medRxiv preprint doi: https://doi.org/10.1101/2020.06.19.20130302; this version posted June 22, 2020. The copyright holder for this preprint (which was not certified by peer review) is the author/funder, who has granted medRxiv a license to display the preprint in perpetuity.

All rights reserved. No reuse allowed without permission.

\title{
Holistic Structural Visualization of Coronary Arteries with Single-catheter Dual- modality Intravascular Imaging Combining IVUS and OFDI
}

Author: Jian Ren, $\mathrm{PhD}^{\mathrm{a}}$, Milen Shishkov, $\mathrm{PhD}^{\mathrm{a}}$, Martin Villiger, $\mathrm{PhD}^{\mathrm{a}}$, Kenichiro Otsuka, MD, PhDa; Seemantini Nadkarni, PhDa, and Brett Bouma, PhDa,b

Total word count: 5,329, including text, table, and figure legends. 34 references, 5 figures, and 1 supplementary table.

Brief title: Intravascular Holistic Structural Visualization with Ultrasound and OFDI: IVHSV

Affiliation: ${ }^{a}$ Wellman Center for Photomedicine, Massachusetts General Hospital, Harvard Medical School, Boston, MA USA; ' Institute for Medical Engineering and Science, Massachusetts Institute of Technology, Cambridge, MA USA.

Financial support: This work was supported by the National Institutes of Health (P41EB015903, K99AG059946, and R01 HL119065) and by Terumo Corporation.

Relationship with industry: Massachusetts General Hospital has patent licensing arrangements with Terumo Corporation. Drs. Bouma and Villiger have the right to receive royalties as part of the licensing arrangements. All other authors have reported that they have no relationships relevant to the contents of this paper to disclose.

\section{Address for correspondence:}

Jian Ren, PhD

Wellman Center for Photomedicine

Massachusetts General Hospital

Harvard Medical School

40 Blossom St

Boston, MA 02114, USA

iren@mgh.harvard.edu

Tel: +1 617-726-4350

Fax: +1 617-726-4103 


\section{Highlights:}

- A catheter-based imaging system integrating ultrasound and optical frequency domain imaging enables real time intravascular holistic structural visualization (IV-HSV) of coronary arterial lesions with a single pullback during cardiac catheterization procedures.

- A computational method to automatically fuse images from both modalities generates a single complete map of vessel wall structures - the IV-HSV image, which offers holistic investigation of coronary plaque key features, such as fibrous cap thickness, calcification, and plaque burden.

- The visualization of plaque morphology along the entire extent of the coronary arterial wall reveals vital information for guiding percutaneous coronary interventions and for advancing our understanding of the pathophysiology of coronary artery diseases. 
medRxiv preprint doi: https://doi.org/10.1101/2020.06.19.20130302; this version posted June 22, 2020. The copyright holder for this preprint (which was not certified by peer review) is the author/funder, who has granted medRxiv a license to display the preprint in perpetuity.

All rights reserved. No reuse allowed without permission.

\section{Visual abstract:}
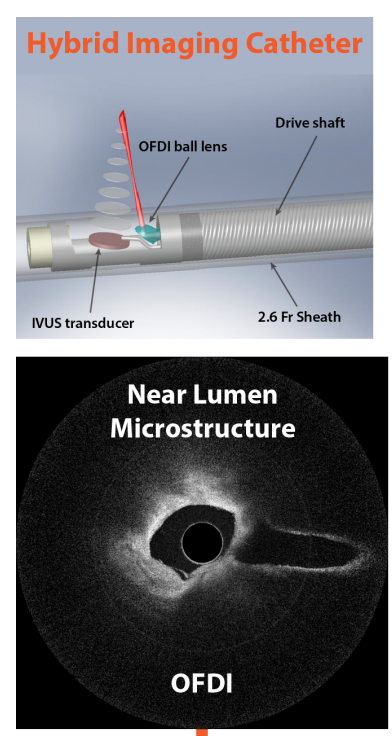

Near Lumen Microstructure
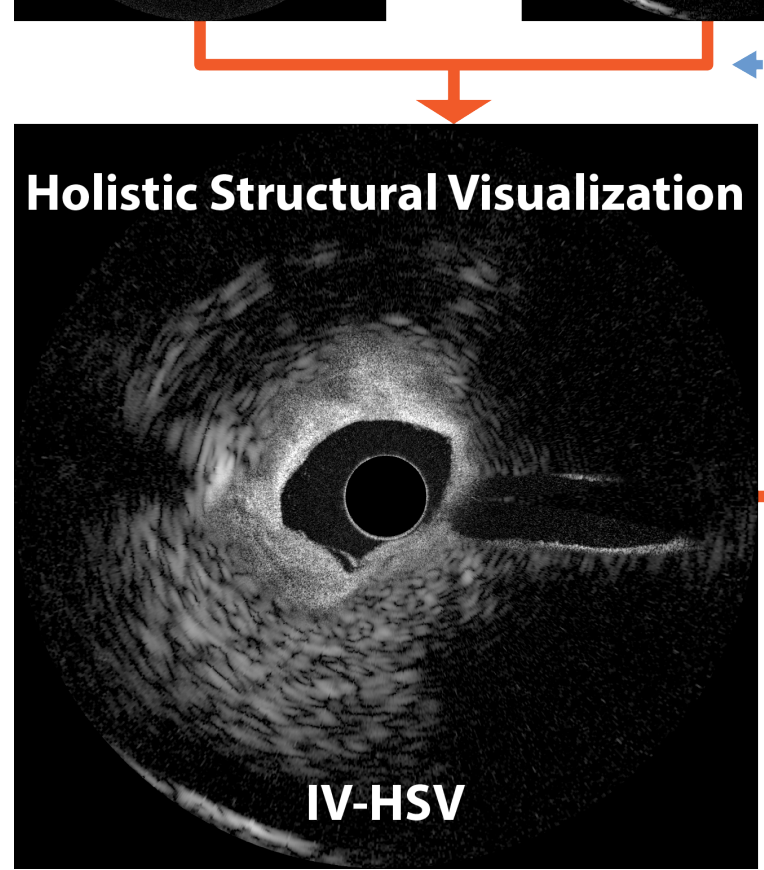

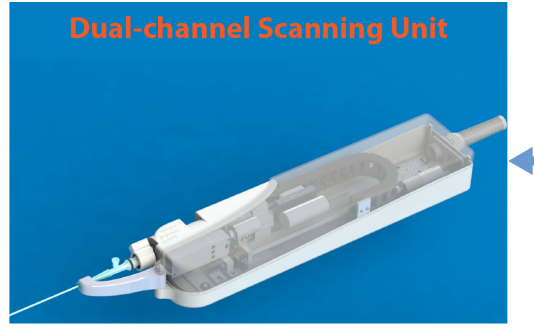

Whole Vessel Wall Macrostructure

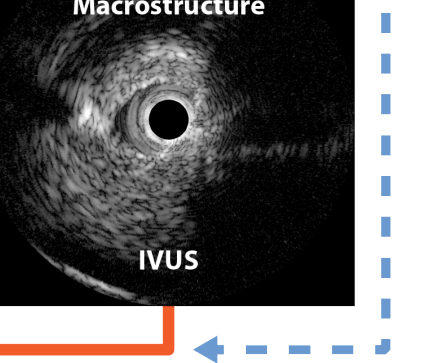

-+- Hardware

and

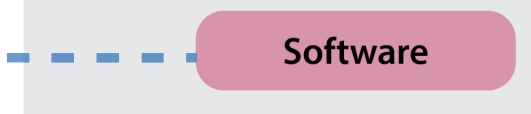

work together to provide one complete map of vessel wall structures that can improve the diagnosis of coronary plaques during cardiac catheterization procedures.

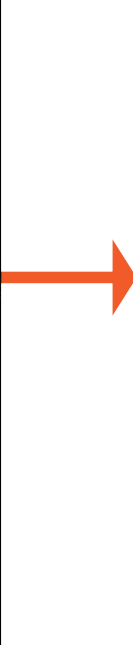

\section{Multiple Metrics Characterized} by a Single Pullback

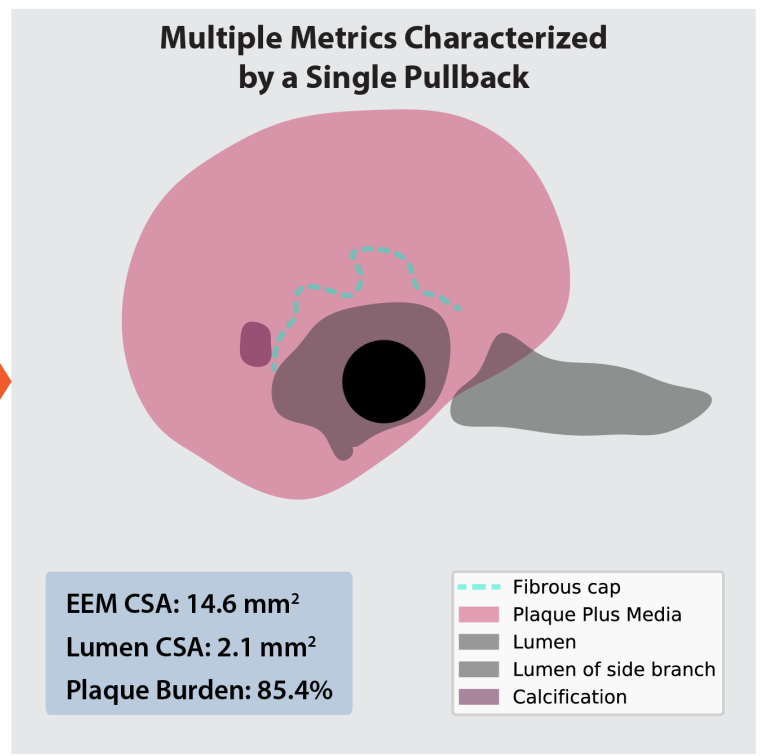


medRxiv preprint doi: https://doi.org/10.1101/2020.06.19.20130302; this version posted June 22, 2020. The copyright holder for this preprint (which was not certified by peer review) is the author/funder, who has granted medRxiv a license to display the preprint in perpetuity.

\section{Summary (250 words):}

Objectives: To test the imaging performance and practical use of a novel dual-modality intravascular imaging system combining intravascular ultrasound (IVUS) and optical coherence tomography (OCT) into a single catheter.

Background: IVUS enables assessing coronary plaque burden, a robust metric for patient prognosis, while OCT and OFDI provide high-resolution images of coronary microstructure and detailed assessment of stent implantation. Owing to their complementary strengths, co-registering IVUS and OFDI provides a more comprehensive assessment of coronary lesions during $\mathrm{PCl}$.

Methods: We developed a 2.6Fr imaging catheter integrating both IVUS and OFDI, interfacing to a dual-modality imaging console through a fast interchange connector. A novel algorithm fuses the IVUS and OFDI signals into a single combined image. We verified the performance of the two modalities and their visualization by imaging of cadaveric coronary arteries and tested practical imaging in the catheterization laboratory in swine in vivo.

Results: Coronary atherosclerotic lesions of cadaver hearts revealed complementary optical and acoustic image features. Spatial co-registration of the modalities was confirmed by high correlation of measured lumen areas. Fused into a combined visualization, dual-modality imaging offers quantitative characterization of lesions, including plaque-burden and fibrous cap thickness. Imaging in vivo does not add procedural complexity compared to conventional single modality imaging.

Conclusion: Dual-modality IVUS/OFDI imaging with fused visualization provides improved assessment of coronary atherosclerotic lesions and is compatible with a 
medRxiv preprint doi: https://doi.org/10.1101/2020.06.19.20130302; this version posted June 22, 2020. The copyright holder for this preprint (which was not certified by peer review) is the author/funder, who has granted medRxiv a license to display the preprint in perpetuity.

All rights reserved. No reuse allowed without permission.

routine clinical setting. Combining the strength of the two modalities offers unique opportunities both as a powerful research instrument and to improve clinical management of patients undergoing $\mathrm{PCl}$.

Key words: intravascular ultrasound, optical coherence tomography, hybrid imaging catheter, fusion image, coronary atherosclerosis 
medRxiv preprint doi: https://doi.org/10.1101/2020.06.19.20130302; this version posted June 22, 2020. The copyright holder for this preprint (which was not certified by peer review) is the author/funder, who has granted medRxiv a license to display the preprint in perpetuity.

\section{Condensed abstract (100 words):}

To facilitate a holistic investigation of coronary arterial lesions for both basic research and clinical interventions, this work presents a catheter-based imaging system integrating IVUS and OFDI, as well as a new rendering method that computationally fuses the intrinsically co-registered images from both modalities into a single crosssectional map of vessel structures. Imaging human cadaveric coronary arteries shows the benefit of this system by revealing near-lumen microstructures and spatially correlated macrostructures deep inside the vessel wall. The co-registration accuracy and operation in a clinical setting of this system was demonstrated through swine catheterization in vivo. 
medRxiv preprint doi: https://doi.org/10.1101/2020.06.19.20130302; this version posted June 22, 2020. The copyright holder for this preprint (which was not certified by peer review) is the author/funder, who has granted medRxiv a license to display the preprint in perpetuity.

All rights reserved. No reuse allowed without permission.

\section{Abbreviations and Acronyms:}

ACS

acute coronary syndrome

CSA

cross sectional area

EEM

external elastic membrane

IV-HSV

intravascular holistic structural visualization

IVUS

intravascular ultrasound

LAD

left anterior descending artery

LCX

left circumflex artery

OCT

optical coherence tomography

OFDI

optical frequency domain imaging

$\mathrm{PCl}$

percutaneous coronary intervention

TCFA

thin-capped fibroatheroma 
medRxiv preprint doi: https://doi.org/10.1101/2020.06.19.20130302; this version posted June 22, 2020. The copyright holder for this preprint (which was not certified by peer review) is the author/funder, who has granted medRxiv a license to display the preprint in perpetuity.

\section{Introduction}

The role of intravascular ultrasound (IVUS) and optical coherence tomography (OCT) in the guidance of percutaneous coronary intervention $(\mathrm{PCl})$ in patients with coronary artery disease has been the subject of extensive investigation (1-4). These intravascular imaging modalities have also deepened our understanding of the pathophysiology of acute coronary syndromes (ACS) and vascular tissue response to stent implantation and drug therapy (5-7). The deep signal penetration of IVUS affords imaging through even the most stenotic lesions and enables measuring coronary plaque burden, which has been shown to be a robust predictor of long-term cardiovascular outcomes $(8,9)$. OCT modalities, such as optical frequency domain imaging (OFDI), reveal near lumen microstructure at a much higher resolution of $10-15 \mu \mathrm{m}(10,11)$, detecting fine structural features of coronary atherosclerosis and implanted stents, that are clinically relevant to identify the culprit lesion and guide stent sizing (3). Yet, no single modality provides complete visualization of coronary plaque, including delineation of fibrous cap, identification of calcification, and evaluation of lesion depth (12).

Post mortem and clinical studies using both IVUS and OCT/OFDI have demonstrated that their combination improves detection of thin-capped fibroatheromas (TCFAs) $(13,14)$ and enables accurate biomechanical modelling of plaque structural stress (15-17). However, the use of independent, standalone IVUS and OCT/OFDI instruments employed in these studies is impractical in a routine clinical setting, entails potentially imperfect co-registration, and impairs real-time analysis. To address these limitations, dual-modality imaging systems have been recently developed to conduct simultaneous IVUS and OCT/OFDI imaging through a single hybrid imaging catheter. 
medRxiv preprint doi: https://doi.org/10.1101/2020.06.19.20130302; this version posted June 22, 2020. The copyright holder for this preprint (which was not certified by peer review) is the author/funder, who has granted medRxiv a license to display the preprint in perpetuity.

All rights reserved. No reuse allowed without permission.

From the proof-of-concept benchtop demonstration (18) to the first-in-human images (19), a number of developments have been achieved to increase the frame rate (20), improve the image quality, and miniaturize the catheters of varying distal designs (2125). Tested in a wide range of vascular specimens, these combined systems have confirmed their potential for clinical adoption $(19,26)$.

We developed an integrated IVUS-OFDI system that implements critical technical improvements to enable simple and reliable operation in cardiac catheterization laboratories. Our system consists of an imaging console offering concurrent OFDI and IVUS video rate imaging with a pullback speed of up to $20 \mathrm{~mm} / \mathrm{s}$. The clinical grade catheters comprise an optical ball lens and an ultrasonic transducer in a $2.6 \mathrm{Fr}$, lowprofile design. A dual-channel rotary joint provides parallel optical and electrical connections and allows for a fast interchange of the disposable catheters. Furthermore, we developed a computational method to automatically fuse the co-registered IVUSOFDI cross-sectional images, providing macro- and micro-structural features of coronary atherosclerotic plaques in a single image. Here, we present the dual-modality IVUS-OFDI system and report on imaging experiments with human cadaver hearts and swine in vivo, demonstrating the unique benefits of this hybrid imaging system in the catheterization laboratory.

\section{Methods}

Integrated IVUS-OFDI imaging system

\section{Dual-modality catheter}


medRxiv preprint doi: https://doi.org/10.1101/2020.06.19.20130302; this version posted June 22, 2020. The copyright holder for this preprint (which was not certified by peer review) is the author/funder, who has granted medRxiv a license to display the preprint in perpetuity.

All rights reserved. No reuse allowed without permission.

To ensure compatibility with $\mathrm{PCl}$ procedures in clinical practice, the hybrid catheter was engineered to integrate the imaging components for both modalities into a single narrow-gauge assembly. As illustrated in Figure 1A, the distal end incorporates an optical ball-lens with a diameter of $\sim 200 \mu \mathrm{m}$ and a single-element ultrasound transducer with a side dimension of $0.5 \mathrm{~mm}$. The angle-polished surface of the ball-lens is metalized to deflect the optical beam towards the vessel wall at a focal distance of $2.6 \mathrm{~mm}$ from the catheter center. The optical and ultrasound beams are aligned by adjusting the orientations of the transducer and the angle-polished surface during catheter assembly. The two imaging components are encased in an open metal housing with an overall outer diameter of $0.6 \mathrm{~mm}$ and a rigid length of $1.3 \mathrm{~mm}$. A single mode optical fiber guides OFDI light between the ball-lens and a self-aligning angle-polished fiber connector at the proximal end of the catheter. The ultrasonic transducer is electrically connected to a customized radio-frequency (RF) connector at the proximal end via a pair of 34-gauge copper wires. The optical fiber and the RF wires are bonded to a torque cable that serves as the drive shaft for the circumferential scanning. The entire assembly fits into a clinical-grade sheath, which has a $2.6 \mathrm{Fr} / 3.2 \mathrm{Fr} 132 \mathrm{~cm}$ monorail design compatible with standard 0.014 " guidewires (Figure 1B). The proximal end connectors are disclosed in the inset of Figure 1B.

\section{Dual-channel scanning unit}

A hybrid optical-electrical rotary interface was developed to connect the catheter comprising the spinning dual-modality imaging probe to the static imaging console for concurrent transmission of both OFDI and IVUS signals. A mechanical locking mechanism is employed to secure the dual-channel connection with a simple click-on, 
medRxiv preprint doi: https://doi.org/10.1101/2020.06.19.20130302; this version posted June 22, 2020. The copyright holder for this preprint (which was not certified by peer review) is the author/funder, who has granted medRxiv a license to display the preprint in perpetuity.

All rights reserved. No reuse allowed without permission.

facilitating fast interchange of the disposable catheters between catheterization procedures. Two motor drive axes drive the hybrid rotary interface. One of them is used to spin the hybrid rotary interface supporting $>100$ rotations per second. The rotary interface and its driving motor are mounted on a customized linear stage. The second motor translates the stage and the connected imaging probe relative to the static outer sheath to achieve pullbacks with a travel range of $20 \mathrm{~cm}$ and a speed ranging from 5$20 \mathrm{~mm} / \mathrm{s}$. To enhance the system reliability, a motor control subsystem operates independently of the imaging console dedicated to signal acquisition and processing. It coordinates all motion sequences, including catheter rotation, pullback, automatic advancing for resetting catheter position, and optimal positioning for catheter interchange.

\section{Dual-modality imaging console}

The console integrates the OFDI and IVUS subsystems into a single mobile cart. The OFDI subsystem utilizes a custom-made wavelength-swept laser, providing axial scans at $50 \mathrm{kHz}$ repetition rate and delivering $10 \mathrm{~mW}$ of optical power onto the tissue. The 110 $\mathrm{nm}$ wavelength range of this source is centered at $1300 \mathrm{~nm}$ for optimal cardiac tissue penetration, offering an axial resolution of $\sim 7 \mu \mathrm{m}$. Balanced and polarization-diverse detection of the OFDI interference signal avoids polarization fading and yields a system sensitivity of $106 \mathrm{~dB}$. The IVUS subsystem employs a customized pulser/receiver operating at a carrier frequency of $40 \mathrm{MHz}$ with a fractional bandwidth of $50 \%$. The pulser/receiver operates at a repetition rate of $25 \mathrm{kHz}$ derived from the $50 \mathrm{kHz}$ OFDI trigger signal using a standalone programmable input/output device. This timing mechanism results in the synchronized acquisitions of both modalities at a ratio of 2:1 
medRxiv preprint doi: https://doi.org/10.1101/2020.06.19.20130302; this version posted June 22, 2020. The copyright holder for this preprint (which was not certified by peer review) is the author/funder, who has granted medRxiv a license to display the preprint in perpetuity.

All rights reserved. No reuse allowed without permission.

(OFDI/IVUS). Adjusting the catheter rotation to acquire 1024 IVUS axial scans and 2048

OFDI axial scans per frame results in a frame rate of 24.8 frames per second. A

custom-developed $\mathrm{C}++$ application continuously streams the digitized data to a RAID hard-drive array, ensuring uninterrupted data acquisition. A subset of the data is processed and visualized in real-time, achieving processing and rendering of about 22 frames per second. While the real-time performance varies slightly depending on the instantaneous CPU load, the data streaming and recording have highest priority to avoid data loss and ensure offline analysis of the complete dataset. The application also includes routines and graphical user-interfaces to configure and control the various system components, and communicates with the control subsystem of the scanning unit.

\section{Intravascular holistic structural visualization (IV-HSV)}

We developed a computational method to fuse inherently co-registered IVUS-OFDI image pairs into single structural images of the vessel wall, representing subsurface microstructure with OFDI and transitioning to IVUS for depths beyond the reach of the OFDI signal (Figure 2). First, the OFDI and IVUS cross-sectional images are scaled to represent actual dimensions by considering the refractive index and the acoustic impedance of the flushing medium. After this geometric calibration, the border where the OFDI signal starts to transition to the IVUS signal is automatically determined by analyzing the OFDI intensity radial profile. An intensity threshold and a thickness parameter are used to locate the depth where the OFDI signal is depleted or is most likely dominated by multiply scattered light. The error function with a width of $90 \mu \mathrm{m}$ is used to define a smooth transition, by creating weight masks that are applied to the 
medRxiv preprint doi: https://doi.org/10.1101/2020.06.19.20130302; this version posted June 22, 2020. The copyright holder for this preprint (which was not certified by peer review) is the author/funder, who has granted medRxiv a license to display the preprint in perpetuity.

All rights reserved. No reuse allowed without permission.

OFDI and IVUS images. The final fused image is the weighted sum of the image pair using these masks.

\section{Intracoronary imaging in cadaveric human heart}

Cadaver human hearts were accrued from the National Disease Research Interchange under a protocol approved by the institutional review board at the Massachusetts General Hospital. Hearts were collected within 24 hours after death and stored at -80 degree Celsius. Tissues were properly thawed before imaging experiments. Left anterior descending artery (LAD), left circumflex artery (LCX), and right coronary artery segments with perivascular tissues were resected from the hearts. A custom fixture was used to mount the artery segments and ensure accurate co-registration with histopathology (27). The proximal end of the segments was connected to a Y-shape Luer connector, allowing for both saline or contrast flushing and catheter access. Side branches were ligated to avoid fluid leakage. The catheter was deployed with a 0.014inch guidewire that was withdrawn for imaging. During pullback imaging, saline was manually flushed through the segments.

After imaging, frozen sections of the arterial samples were prepared for histopathology. Arterial segments were snap frozen within their fixtures. To facilitate accurate co-registration, the fixtures contain vertical slots to enable cutting of the tissue blocks into smaller segments. Two consecutive $7 \mu \mathrm{m}$-thick sections were collected every $1 \mathrm{~mm}$ along the artery segments and processed for hematoxylin-eosin (H\&E) and Trichrome staining, respectively. Each slide was digitized with NanoZoomer (Hamamatsu Photonics, K.K.) for further analysis.

\section{Live swine catheterization and imaging}


medRxiv preprint doi: https://doi.org/10.1101/2020.06.19.20130302; this version posted June 22, 2020. The copyright holder for this preprint (which was not certified by peer review) is the author/funder, who has granted medRxiv a license to display the preprint in perpetuity.

All rights reserved. No reuse allowed without permission.

For practical testing of the dual-modality system in the cardiac catheterization lab at the Massachusetts General Hospital, we conducted intravascular imaging in vivo in a healthy Yorkshire pig under deep anesthesia. Vital signals were monitored throughout the entire procedure. A 7 Fr guide catheter was placed through the carotid artery to gain access to the coronary arteries. Both the LAD and LCX were catheterized using a 0.014-inch guidewire (Figure 5A). A total of fourteen $60 \mathrm{~mm}$-long pullbacks were acquired at various pullback speeds $(5-20 \mathrm{~mm} / \mathrm{s})$. Contrast injection was manually performed to displace circulating blood in the imaged coronary artery to ensure good image quality for OFDI. The study followed the regulations of Massachusetts General Hospital and with generally accepted guidelines governing such work.

\section{IV-HSV image analysis}

The fused dual-modality images visualize multiple important anatomic structures that are relevant for characterizing atherosclerotic lesions (visual abstract). We segmented the lumen, calcifications, fibrous cap boundary, and side-branches in OFDI images and the EEM in IVUS images. Based on the segmentations, the percent plaque plus media CSA (\%Plaque burden) was calculated as:

$$
\% \text { Plaqueburden }=\frac{\text { EEMCSA-luminalCSA }}{E E M C S A} \times 100
$$

The fusion processing, the image rendering, and the calculation of the CSAs and the plaque burden were all automated in Python.

To demonstrate the accuracy of the intrinsic co-registration of this dual-modality imaging system, we compared the luminal CSA measured independently in the properly scaled OFDI and IVUS cross-sectional images using Pearson's correlation analysis. The lumen was manually segmented with custom-built MATLAB routines. Evaluation of 
medRxiv preprint doi: https://doi.org/10.1101/2020.06.19.20130302; this version posted June 22, 2020. The copyright holder for this preprint (which was not certified by peer review) is the author/funder, who has granted medRxiv a license to display the preprint in perpetuity.

the areas and statistical analysis were performed with custom Python routines and the SciPy.stat package.

\section{Results}

\section{Visualization of coronary plaques with dual-modality imaging}

First, we imaged a human cadaver heart with the dual-modality system, where various coronary plaque features were visualized. Demonstrating typical fibroatheromata, Figure 3 displays the IV-HSV images, generated by optimally merging the intrinsically co-registered OFDI and IVUS cross-sectional images, together with the segmentation of individual plaque features and matching histology. The IV-HSV image (Figure 3-A1) clearly renders the lumen shape and the fibrous cap as captured by OFDI, complemented by deeper plaque structures and the entire circumference of the vessel wall disclosed by IVUS. Notably, the fusion algorithm automatically selected OFDI to depict the near-lumen microstructure of the vessel injury at 6-8 o'clock with high resolution, which is more challenging to identify in the IVUS image. Furthermore, segmentation of the IV-HSV image enabled quantitative measurements of luminal CSA and EEM CSA providing the plaque burden of the fibroatheroma as percentage (Figure 3-A4 and B4). The cross-section in Figure 3B is located close to a side branch. While both OFDI and IVUS cross-sectional images visualize the side branch at 3 o'clock - an important anatomical landmark during $\mathrm{PCI}$ - the OFDI image reveals its morphology with higher fidelity. Determined by the fusion algorithm, the side branch is represented by its OFDI appearance in the IV-HSV image, preferable for providing the best assessment of vessel morphology. 
medRxiv preprint doi: https://doi.org/10.1101/2020.06.19.20130302; this version posted June 22, 2020. The copyright holder for this preprint (which was not certified by peer review) is the author/funder, who has granted medRxiv a license to display the preprint in perpetuity.

All rights reserved. No reuse allowed without permission.

Figure 4A displays a further interesting example of an atherosclerotic lesion. The conventional OFDI image suggests a lipid-rich plaque and discloses a thrombus-like structure on the luminal surface (Figure 4-A2). Histopathology confirmed the presence of newer intimal tissue on top of a pathological intimal thickening (Figure 4-A6). While the OFDI appearance mimicked a fibroatheroma, the co-registered IVUS image clearly depicts the EEM behind a lesion with only a modest amount of lipid. However, the newer intimal structure clearly visualized in the OFDI image is challenging to appreciate in the IVUS image (Figure 4-A3). Owing to the complementarity of the underlying imaging modalities, the IV-HSV image reveals structures across the entire diameter of the vessel wall and with high resolution close to the lumen, enabling the accurate estimation of plaque burden (Figure 4-A4 and -A5).

Figure 4B presents a fibro-calcified plaque with lipid pool. The OFDI image (Figure 4-B2) delineates the detailed geometry of the calcification and the upper boundary of the lipid pool, in close agreement with histology (Figure 4-B6). In OFDI, calcifications appear translucent and with a well-defined border. In comparison, the large difference in acoustic impedance between calcified and surrounding tissue casts an acoustic shadow that prevents IVUS from imaging behind calcified tissue or determining its depth (Figure 4-B3). Combined, the IV-HSV image (Figure 4-B1) clearly visualizes the arterial lumen and the EEM of the vessel, facilitating the characterization of various plaque features within a single map.

\section{Dual-modality IVUS-OFDI in swine coronary artery in vivo}

Next, we examined the utility and performance of the dual-modality IVUS-OFDI system in the cardiac catheterization laboratory. Figure 5 provides an overview of the imaging 
medRxiv preprint doi: https://doi.org/10.1101/2020.06.19.20130302; this version posted June 22, 2020. The copyright holder for this preprint (which was not certified by peer review) is the author/funder, who has granted medRxiv a license to display the preprint in perpetuity.

All rights reserved. No reuse allowed without permission.

with the system in the coronary arteries of a healthy swine. Figure $5 \mathrm{D}, 5 \mathrm{E}, 5 \mathrm{G}$, and $5 \mathrm{H}$ show intrinsically co-registered dual-modality IVUS-OFDI cross-sectional images acquired in the LAD, at a pullback rate of $10 \mathrm{~mm} / \mathrm{s}$. Both OFDI (Figure 5D and 5G) and IVUS (Figure 5E and 5H) images show matching side branch locations. In addition, the Pearson's correlation analysis (Figure 5B) demonstrates an excellent correlation between luminal CSA measured with OFDI and IVUS $(r=0.97, p<0.001)$. The BlandAltman plot (Figure 5C) suggests neither the measurement bias $\left(-0.07 \mathrm{~mm}^{2}\right)$ nor the limits of agreement $\left(0.25\right.$ and $\left.-0.38 \mathrm{~mm}^{2}\right)$ is clinically important. Both Figure $5 \mathrm{~B}$ and $5 \mathrm{C}$ validated the intrinsic co-registration of the two modalities.

\section{Discussion}

The present study reports on the development of an intravascular dual-modality imaging system integrating IVUS and OFDI into a single catheter enabling fast interchange required for ease of operation in the catheterization laboratory. We further developed a novel computational method to fuse the cross-sectional images from the two modalities for convenient visualization of the macro- and microstructures of coronary plaques - IVHSV. Imaging of swine coronary arteries in vivo with the dual-modality system demonstrated accurate intrinsic co-registration of cross-sectional OFDI and IVUS images acquired simultaneously with a single pullback, which is unattainable by using the two imaging modalities sequentially. Translated to the clinic, the IV-HSV of this dualmodality IVUS-OFDI system would provide a holistic assessment of coronary arterial lesions and may help refine intervention and management strategies for patients undergoing $\mathrm{PCl}$. 
medRxiv preprint doi: https://doi.org/10.1101/2020.06.19.20130302; this version posted June 22, 2020. The copyright holder for this preprint (which was not certified by peer review) is the author/funder, who has granted medRxiv a license to display the preprint in perpetuity.

\section{Development of the dual-modality system}

The physical alignment of the optical and acoustic beams ensures spatial co-registration of the IVUS and OFDI axial scans. The absence of rotational or longitudinal offsets between the two modalities found in previous work (rotational $90^{\circ}(25), 180^{\circ}(24)$, longitudinal $2 \mathrm{~mm}(23))$, eliminates potential rotational co-registration errors due to nonuniform rotational distortion as well as longitudinal co-registration errors due to cardiac motion. Furthermore, the synchronization scheme of the acquisition system guarantees temporal co-registration of the axial scans of both modalities. Both the temporal synchronization and the physical beam alignment contribute to the highly accurate correlation of vessel structures in the obtained images. It is worth noting that there are small longitudinal and angular offsets between the optical and acoustic beams, as shown in Figure 1A. The angular offset is introduced to compensate the longitudinal offset so that two beams have the largest overlap along the imaging depth. Compared to IVUS resolution, the overall misalignment is sufficiently small to be ignored, as confirmed by Figure 5B and 5C.

The integration of both optical and acoustic sensing into a single catheter required special considerations for its distal design. Ultrasound transmission requires immersion of the distal assembly in an echolucent medium, requiring flushing of the open-ended catheter sheath with saline. Therefore, the optical components inevitably need to operate in the same aqueous environment. In contrast to conventional OFDI catheters, where refraction happens at the glass-air interface of the ball lens within a sealed catheter sheath, the refractive index $(\mathrm{RI})$ surrounding the ball lens is increased in the present case from 1 (air) to about 1.3 (water), a value much closer to the RI of the 
medRxiv preprint doi: https://doi.org/10.1101/2020.06.19.20130302; this version posted June 22, 2020. The copyright holder for this preprint (which was not certified by peer review) is the author/funder, who has granted medRxiv a license to display the preprint in perpetuity.

All rights reserved. No reuse allowed without permission.

silica-based ball lens (1.43). This posed two challenges. First, conventional OFDI catheters employ total internal reflection at the angle-polished surface of the ball lens to deflect the beam towards the vessel wall. This effect is frustrated when immersed in a higher RI and ceases to take place. Instead, we metalized the angle-polished surface to cause the beam to deflect regardless of the surrounding mediums' RI. Second, the reduced $\mathrm{RI}$ contrast between the medium and the glass lowers the refractive power of the curved interface. To maintain a high-quality near-lumen optical focus, we significantly reduced the diameter of the ball lens to about $200 \mu \mathrm{m}$. Although this dimension approaches its lower limit - the diameter of the fiber $(125 \mu \mathrm{m})$, our fabrication process produced ball lenses with very consistent quality.

\section{IV-HSV of coronary plaques and vessels}

Dual-modality IVUS-OFDI imaging offers unique opportunities for both research and clinical use by characterizing both micro- and macro-structures of coronary atherosclerotic lesions with a single imaging procedure. OFDI has been utilized to resolve various intravascular structures at a resolution of $<20 \mu \mathrm{m}$. Nevertheless, its imaging depth is limited to $1-2 \mathrm{~mm}$ by tissue scattering. On the other hand, IVUS penetrates through the entire vessel wall, offering estimation of plaque burden and insight into the composition of large plaques. However, its inferior resolution of several hundred microns prevents the visualization of fine tissue microstructures. In light of the individual modalities' complementary traits, the proposed IV-HSV imaging provides a more comprehensive examination of coronary atherosclerotic lesions. Supplemental table 1 compares the capability of IVUS, OFDI and the dual-modality system of visualizing key features of the coronary arterial wall and implanted stents. 
medRxiv preprint doi: https://doi.org/10.1101/2020.06.19.20130302; this version posted June 22, 2020. The copyright holder for this preprint (which was not certified by peer review) is the author/funder, who has granted medRxiv a license to display the preprint in perpetuity.

All rights reserved. No reuse allowed without permission.

A first example demonstrating the unique benefits of IV-HSV is the estimation of plaque burden. Plaque burden measured with IVUS has been shown to be a robust predictor of short- and long-term cardiovascular outcomes in patients with coronary artery disease $(8,9,28)$. Accurate estimation of plaque burden with OCT/OFDI in lipidrich lesions remains challenging due to insufficient imaging penetration. Efforts using computational algorithms to estimate plaque burden from OCT/OFDI data has shown limited success (29-31). The dual-modality system offers a potentially more accurate estimation of plaque burden than either IVUS or OCT/OFDI alone, because it combines the robust mapping of the EEM available to IVUS with the accurate delineation of the lumen owing to the improved resolution of OCT/OFDI.

Dual-modality imaging may also improve the detection of rupture-prone plaques. Despite significant efforts in advancing intravascular imaging modalities, accurate identification of these plaques in patients remains difficult. Clinical studies have indicated that a large number of TCFAs diagnosed by OCT/OFDI do not cause acute coronary events $(32,33)$. While OCT/OFDI excels at identifying thin fibrous caps, it is prone to overestimating lesion severity owing to its limited imaging depth and it can misclassify pathological intimal thickening as fibroatheroma. The combined use of IVUS and OFDI has been shown to improve the accuracy of identifying TCFAs $(13,14)$. The automatically generated IV-HSV images may facilitate real-time detection of ruptureprone TCFAs with increased accuracy and offer improved risk assessment of no-reflow phenomenon and clinically relevant periprocedural myocardial infarction during $\mathrm{PCl}$.

While previous technical developments enabled the demonstration of the dual modal concept and its First-in-Human application, the current work embodies critical 
medRxiv preprint doi: https://doi.org/10.1101/2020.06.19.20130302; this version posted June 22, 2020. The copyright holder for this preprint (which was not certified by peer review) is the author/funder, who has granted medRxiv a license to display the preprint in perpetuity.

All rights reserved. No reuse allowed without permission.

technical improvements and innovations, including: 1) The new distal probe design offers improved sensor alignment, which, together with the precise timing of image acquisition, results in accurately co-registered IVUS/OFDI image pairs. The refined fabrication processes of sensor elements and the comprehensive optimization of the OFDI and IVUS subsystems contribute to the high image quality. In addition, the innovations in the hybrid rotary joint and catheter packaging ensure consistent system performance for practical application environments. 2) The novel IV-HSV processing synergistically integrates structural maps from both modalities, providing the clinicalrelevant information in real-time. Besides the basic processing and control functionalities, as offered by previous systems, the software systems of the imaging console and the stand-alone motor control unit were customized to maximize safety and usability. Combined, these advances resulted in an intravascular visualization tool with unprecedented image quality and compatible with routine clinical use.

\section{Study limitations}

First, imaging of coronary atherosclerosis was performed in a single of cadaver heart. Intracoronary imaging in vivo was performed in a healthy swine without coronary artery disease. Imaging in patients will be needed to demonstrate robust dual-modality imaging in a clinical setting. Second, the present study did not include imaging of stented coronary arteries. Further studies are needed to investigate whether the fusion algorithm is able to conveniently render stent struts and in-stent neointima for improved investigation of the mechanisms underlying stent thrombosis and in-stent restenosis. Third, the current fusion algorithm entirely relies on the OFDI signal to define the transition from OFDI to IVUS appearance. While this strategy works well for the majority 
medRxiv preprint doi: https://doi.org/10.1101/2020.06.19.20130302; this version posted June 22, 2020. The copyright holder for this preprint (which was not certified by peer review) is the author/funder, who has granted medRxiv a license to display the preprint in perpetuity.

All rights reserved. No reuse allowed without permission.

of coronary lesions, it could result in non-optimal partitioning of the two modalities due to artifacts in OFDI images. Utilizing the joint information from both modalities,

potentially coupled with prior pathophysiological knowledge in the form of a trained deep learning model holds promise to yield more robust and clinical-relevant visualization.

Finally, similar to conventional intravascular OCT/OFDI systems, the dual-modality system requires blood clearing through the injection of contrast media or saline for OFDI imaging. Operation without flushing would preclude OFDI image interpretation, but offer the ability to survey vessels using IVUS alone to locate lesions of interest for targeted dual-modality imaging. This would reduce the amount of used contrast medium and limit the risk of contrast-induced acute kidney injury during PCl (34).

\section{Conclusions}

This study demonstrates the feasibility and prospects of dual-modality IVUS and OCT imaging using an integrated imaging system for the characterization of coronary arterial atherosclerotic lesions. Use of a single clinical-grade, dual-modality imaging catheter and real-time IV-HSV ensure convenient operation in a clinical setting. Owing to the synergy between IVUS and OFDI, IV-HSV imaging offers unique opportunities to study the etiology of coronary atherosclerosis and assess the risk of coronary lesions and clinical outcomes of patients undergoing $\mathrm{PCl}$. 
medRxiv preprint doi: https://doi.org/10.1101/2020.06.19.20130302; this version posted June 22, 2020. The copyright holder for this preprint

(which was not certified by peer review) is the author/funder, who has granted medRxiv a license to display the preprint in perpetuity.

All rights reserved. No reuse allowed without permission.

\section{PERSPECTIVES}

COMPETENCY IN MEDICAL KNOWLEDE: IVUS and OFDI are well-established intravascular imaging methods for guiding PCI. IVUS visualizes the entire vessel wall also in areas of disease, while OFDI images near-lumen microstructures of coronary arteries at high resolution. Combining insight from independent imaging with IVUS and OFDI has been shown to improve the detection of high-risk plaques and the estimation of plaque structural stress, but is impractical in a routine clinical setting. Here, we present a catheter-based imaging system integrating IVUS and OFDI enabling real-time IV-HSV of coronary arteries with a single catheter. IV-HSV images represent automatically fused IVUS and OFDI images in a single complete map of macro- and microstructures of the coronary arterial wall.

TRANSLATIONAL OUTLOOK: The utility of the dual-modality IVUS-OFDI imaging system should be tested in patients with coronary artery disease undergoing PCl. 
medRxiv preprint doi: https://doi.org/10.1101/2020.06.19.20130302; this version posted June 22, 2020. The copyright holder for this preprint (which was not certified by peer review) is the author/funder, who has granted medRxiv a license to display the preprint in perpetuity.

All rights reserved. No reuse allowed without permission.

Acknowledgements: Kenichiro Otsuka acknowledges partial support from the Japan Heart Foundation/Bayer Yakuhin Research Grant Abroad, the Uehara Memorial Foundation Postdoctoral Fellowship, and the Japan Society for the Promotion of Science Overseas Research Fellowship. The authors acknowledge Leon Ptaszek MD, $\mathrm{PhD}$ and Moussa Mansour, MD at the Department of Cardiology, Massachusetts General Hospital for in vivo swine imaging; Diane Tshikudi, MS and Pallavi Doradla, PhD at the Wellman Center for Photomedicine, Massachusetts General Hospital for their assistance in cadaver tissue preparation and histology. 
medRxiv preprint doi: https://doi.org/10.1101/2020.06.19.20130302; this version posted June 22, 2020. The copyright holder for this preprint (which was not certified by peer review) is the author/funder, who has granted medRxiv a license to display the preprint in perpetuity.

All rights reserved. No reuse allowed without permission.

\section{Funding Sources:}

This work was supported by the National Institutes of Health (grants P41EB015903, K99AG059946, and R01HL119065) and by Terumo Corporation. 
medRxiv preprint doi: https://doi.org/10.1101/2020.06.19.20130302; this version posted June 22, 2020. The copyright holder for this preprint

(which was not certified by peer review) is the author/funder, who has granted medRxiv a license to display the preprint in perpetuity.

All rights reserved. No reuse allowed without permission.

\section{Reference:}

1. Mintz GS. Clinical Utility of Intravascular Imaging and Physiology in Coronary Artery Disease. J Am Coll Cardiol 2014;64(2):207 LP - 222. Doi: 10.1016/j.jacc.2014.01.015.

2. Ali ZA., Maehara A., Généreux P., et al. Optical coherence tomography compared with intravascular ultrasound and with angiography to guide coronary stent implantation (ILUMIEN III: OPTIMIZE PCI): a randomised controlled trial. Lancet 2016. Doi: 10.1016/S0140-6736(16)31922-5.

3. Räber L., Mintz GS., Koskinas KC., et al. Clinical use of intracoronary imaging.

Part 1: Guidance and optimization of coronary interventions. An expert consensus document of the European Association of Percutaneous Cardiovascular Interventions. Eur Heart J 2018. Doi: 10.1093/eurheartj/ehy285.

4. Jones DA., Rathod KS., Koganti S., et al. Angiography Alone Versus Angiography Plus Optical Coherence Tomography to Guide Percutaneous Coronary Intervention: Outcomes From the Pan-London PCI Cohort. JACC Cardiovasc Interv 2018. Doi: 10.1016/j.jcin.2018.01.274.

5. Nissen SE., Nicholls SJ., Sipahi I., et al. Effect of very high-intensity statin therapy on regression of coronary atherosclerosis: The ASTEROID trial. J Am Med Assoc 2006. Doi: 10.1001/jama.295.13.jpc60002.

6. Soeda T., Uemura S., Park SJ., et al. Incidence and clinical significance of poststent optical coherence tomography findings: One-year follow-up study from a multicenter registry. Circulation 2015. Doi:

10.1161/CIRCULATIONAHA.114.014704. 
medRxiv preprint doi: https://doi.org/10.1101/2020.06.19.20130302; this version posted June 22, 2020. The copyright holder for this preprint

(which was not certified by peer review) is the author/funder, who has granted medRxiv a license to display the preprint in perpetuity.

All rights reserved. No reuse allowed without permission.

7. Räber L., Taniwaki M., Zaugg S., et al. Effect of high-intensity statin therapy on atherosclerosis in non-infarct-related coronary arteries (IBIS-4): A serial intravascular ultrasonography study. Eur Heart J 2015. Doi: 10.1093/eurheartj/ehu373.

8. Stone GW., Maehara A., Lansky AJ., et al. A prospective natural-history study of coronary atherosclerosis. N Engl J Med 2011. Doi: 10.1056/NEJMoa1002358.

9. Schuurman AS., Vroegindewey MM., Kardys I., et al. Prognostic Value of Intravascular Ultrasound in Patients With Coronary Artery Disease. J Am Coll Cardiol 2018. Doi: 10.1016/j.jacc.2018.08.2140.

10. Brezinski ME., Tearney GJ., Bouma BE., et al. Optical coherence tomography for optical biopsy: Properties and demonstration of vascular pathology. Circulation 1996. Doi: 10.1161/01.CIR.93.6.1206.

11. Bouma BE., Villiger M., Otsuka K., Oh W-Y. Intravascular optical coherence tomography [Invited]. Biomed Opt Express 2017. Doi: 10.1364/boe.8.002660.

12. Bourantas C V., Jaffer FA., Gijsen FJ., et al. Hybrid intravascular imaging: Recent advances, technical considerations, and current applications in the study of plaque pathophysiology. Eur Heart J 2017. Doi: 10.1093/eurheartj/ehw097.

13. Fujii K., Hao H., Shibuya M., et al. Accuracy of OCT, Grayscale IVUS, and Their Combination for the Diagnosis of Coronary TCFA. JACC Cardiovasc Imaging 2015;8(4):451 LP - 460. Doi: 10.1016/j.jcmg.2014.10.015.

14. Nakano M., Yahagi K., Yamamoto H., et al. Additive Value of Integrated Backscatter IVUS for Detection of Vulnerable Plaque by Optical Frequency Domain Imaging: An Ex Vivo Autopsy Study of Human Coronary Arteries. JACC 
medRxiv preprint doi: https://doi.org/10.1101/2020.06.19.20130302; this version posted June 22, 2020. The copyright holder for this preprint

(which was not certified by peer review) is the author/funder, who has granted medRxiv a license to display the preprint in perpetuity.

All rights reserved. No reuse allowed without permission.

Cardiovasc Imaging 2016. Doi: 10.1016/j.jcmg.2015.07.011.

15. Brown AJ., Teng Z., Evans PC., Gillard JH., Samady H., Bennett MR. Role of biomechanical forces in the natural history of coronary atherosclerosis. Nat Rev Cardiol 2016. Doi: 10.1038/nrcardio.2015.203.

16. Costopoulos C., Huang Y., Brown AJ., et al. Plaque Rupture in Coronary Atherosclerosis Is Associated With Increased Plaque Structural Stress. JACC Cardiovasc Imaging 2017. Doi: 10.1016/j.jcmg.2017.04.017.

17. Doradla P., Otsuka K., Nadkarni A., et al. Biomechanical Stress Profiling of Coronary Atherosclerosis: Identifying a Multifactorial Metric to Evaluate Plaque Rupture Risk. JACC Cardiovasc Imaging 2019. Doi: https://doi.org/10.1016/j.jcmg.2019.01.033.

18. Yin J., Yang H-C., Li X., et al. Integrated intravascular optical coherence tomography ultrasound imaging system. J Biomed Opt 2010;15(1):010512. Doi: 10.1117/1.3308642.

19. Sheth TN., Pinilla-Echeverri N., Mehta SR., Courtney BK. First-in-Human Images of Coronary Atherosclerosis and Coronary Stents Using a Novel Hybrid Intravascular Ultrasound and Optical Coherence Tomographic Catheter. JACC Cardiovasc Interv 2018;11(23):2427-30. Doi: 10.1016/j.jcin.2018.09.022.

20. Li J., Ma T., Mohar D., et al. Ultrafast optical-ultrasonic system and miniaturized catheter for imaging and characterizing atherosclerotic plaques in vivo. Sci Rep 2016;5(1):18406. Doi: 10.1038/srep18406.

21. Hao-Chung Yang., Jiechen Yin., Changhong Hu., et al. A dual-modality probe utilizing intravascular ultrasound and optical coherence tomography for 
medRxiv preprint doi: https://doi.org/10.1101/2020.06.19.20130302; this version posted June 22, 2020. The copyright holder for this preprint

(which was not certified by peer review) is the author/funder, who has granted medRxiv a license to display the preprint in perpetuity.

All rights reserved. No reuse allowed without permission.

intravascular imaging applications. IEEE Trans Ultrason Ferroelectr Freq Control 2010;57(12):2839-43. Doi: 10.1109/TUFFC.2010.1758.

22. Li X., Yin J., Hu C., Zhou Q., Shung KK., Chen Z. High-resolution coregistered intravascular imaging with integrated ultrasound and optical coherence tomography probe. Appl Phys Lett 2010;97(13):133702. Doi: 10.1063/1.3493659.

23. Yin J., Li X., Jing J., et al. Novel combined miniature optical coherence tomography ultrasound probe for in vivo intravascular imaging. J Biomed Opt 2011;16(6):060505. Doi: 10.1117/1.3589097.

24. Li J., Ma T., Jing J., et al. Miniature optical coherence tomography-ultrasound probe for automatically coregistered three-dimensional intracoronary imaging with real-time display. J Biomed Opt 2013;18(10):100502. Doi:

10.1117/1.JBO.18.10.100502.

25. Li BH., Leung ASO., Soong A., et al. Hybrid intravascular ultrasound and optical coherence tomography catheter for imaging of coronary atherosclerosis. Catheter Cardiovasc Interv 2013;81(3):494-507. Doi: 10.1002/ccd.24295.

26. Li J., Li X., Mohar D., et al. Integrated IVUS-OCT for Real-Time Imaging of Coronary Atherosclerosis. JACC Cardiovasc Imaging 2014;7(1):101-3. Doi: 10.1016/j.jcmg.2013.07.012.

27. Gardner CM., Tan H., Hull EL., et al. Detection of Lipid Core Coronary Plaques in Autopsy Specimens With a Novel Catheter-Based Near-Infrared Spectroscopy System. JACC Cardiovasc Imaging 2008;1(5):638-48. Doi:

10.1016/j.jcmg.2008.06.001.

28. Sato A., Aonuma K. Coronary plaque morphology on multi-modality imagining and 
medRxiv preprint doi: https://doi.org/10.1101/2020.06.19.20130302; this version posted June 22, 2020. The copyright holder for this preprint

(which was not certified by peer review) is the author/funder, who has granted medRxiv a license to display the preprint in perpetuity.

All rights reserved. No reuse allowed without permission.

periprocedural myocardial infarction after percutaneous coronary intervention. IJC Hear Vasc 2016. Doi: 10.1016/j.ijcha.2016.03.009.

29. Räber L., Heo JH., Radu MD., et al. Offline fusion of co-registered intravascular ultrasound and frequency domain optical coherence tomography images for the analysis of human atherosclerotic plaques. Eurolntervention 2012;8(1):98-108. Doi: 10.4244/EIJV8I1A16.

30. Kubo T., Yamano T., Liu Y., et al. Feasibility of optical coronary tomography in quantitative measurement of coronary arteries with lipid-rich plaque. Circ J 2015. Doi: 10.1253/circj.CJ-14-1085.

31. Gerbaud E., Weisz G., Tanaka A., et al. Plaque burden can be assessed using intravascular optical coherence tomography and a dedicated automated processing algorithm: a comparison study with intravascular ultrasound. Eur Hear J - Cardiovasc Imaging 2019. Doi: 10.1093/ehjci/jez185.

32. Xing L., Higuma T., Wang Z., et al. Clinical Significance of Lipid-Rich Plaque Detected by Optical Coherence Tomography: A 4-Year Follow-Up Study. J Am Coll Cardiol 2017. Doi: 10.1016/j.jacc.2017.03.556.

33. Prati F., Romagnoli E., Gatto L., et al. Relationship between coronary plaque morphology of the left anterior descending artery and 12 months clinical outcome: the CLIMA study. Eur Heart J 2019. Doi: 10.1093/eurheartj/ehz520.

34. Almendarez M., Gurm HS., Mariani J., et al. Procedural Strategies to Reduce the Incidence of Contrast-Induced Acute Kidney Injury During Percutaneous Coronary Intervention. JACC Cardiovasc Interv 2019. Doi: 10.1016/j.jcin.2019.04.055. 
Figures and Figure Legends:

Figure 1. Dual-modality catheter integrating IVUS and OFDI.

(A) Schematic rendering of the distal end. (B) Photograph of an assembled and packaged clinical-grade catheter. The inset displays the RF electrical connection and the angled physical contact (APC) fiber connector.

A

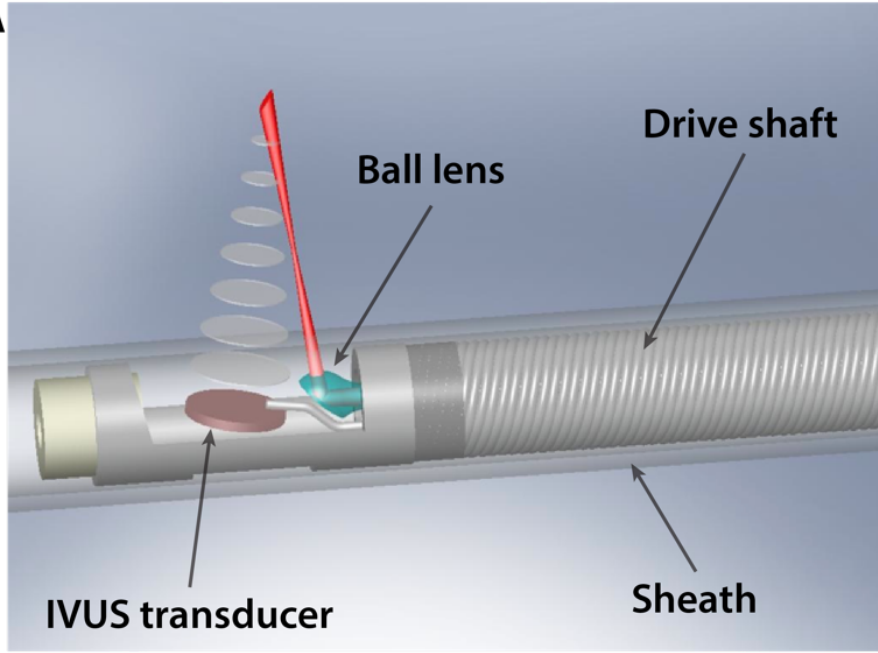

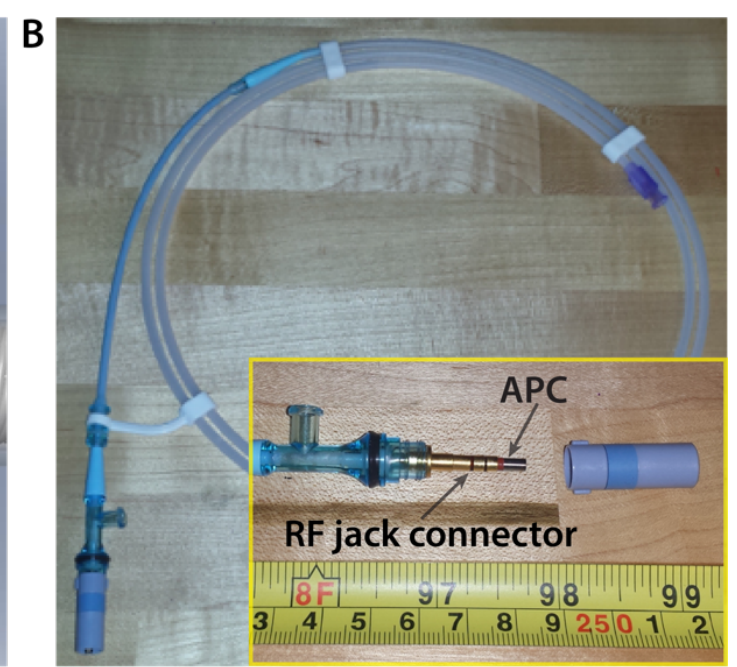


Figure 2. Holistic structural visualization (IV-HSV) of coronary plaques ex vivo.

Representative images of a fibro-calcified plaque (A1 to $\mathbf{A 6})$ and a necrotic core fibroatheroma (B1 to B6). IV-HSV images (A1 and B1) generated by automatically fusing the OFDI (A2 and B2) and IVUS (A3 and B3) cross-sectional images. (A4 and A5) and (B4 and B5) show the magnified views of the square areas of interest indicated in (A1) and (B1), respectively. (A6 and B6) Matching histopathology, stained with hematoxylin and eosin (A6), and trichrome (B6), respectively. Scale bars in (A2, B2) apply to both (A2 and $\mathbf{A} 3$ ) and (B2 and B3), respectively.
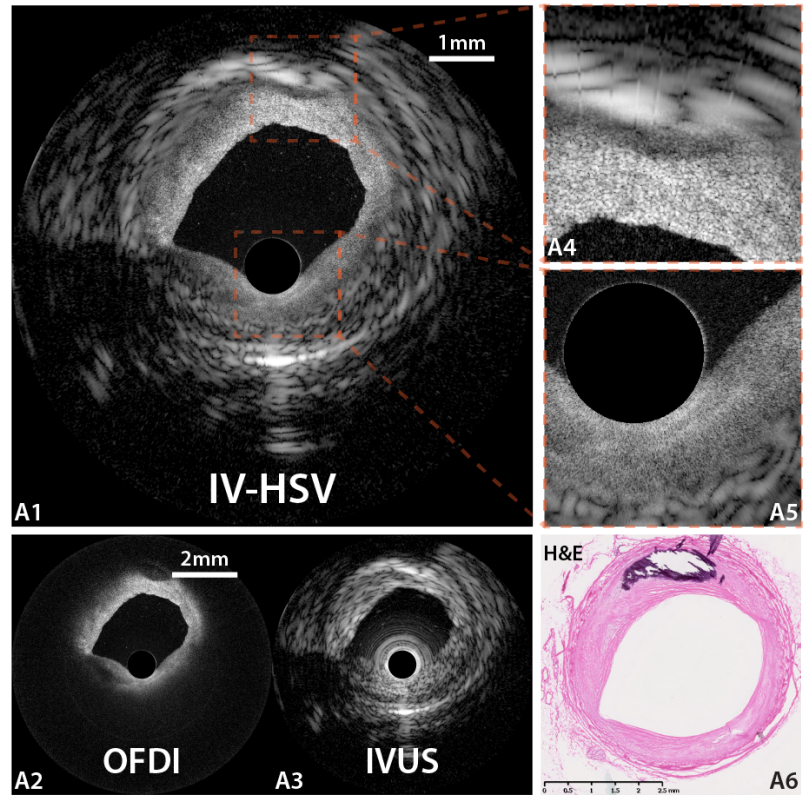
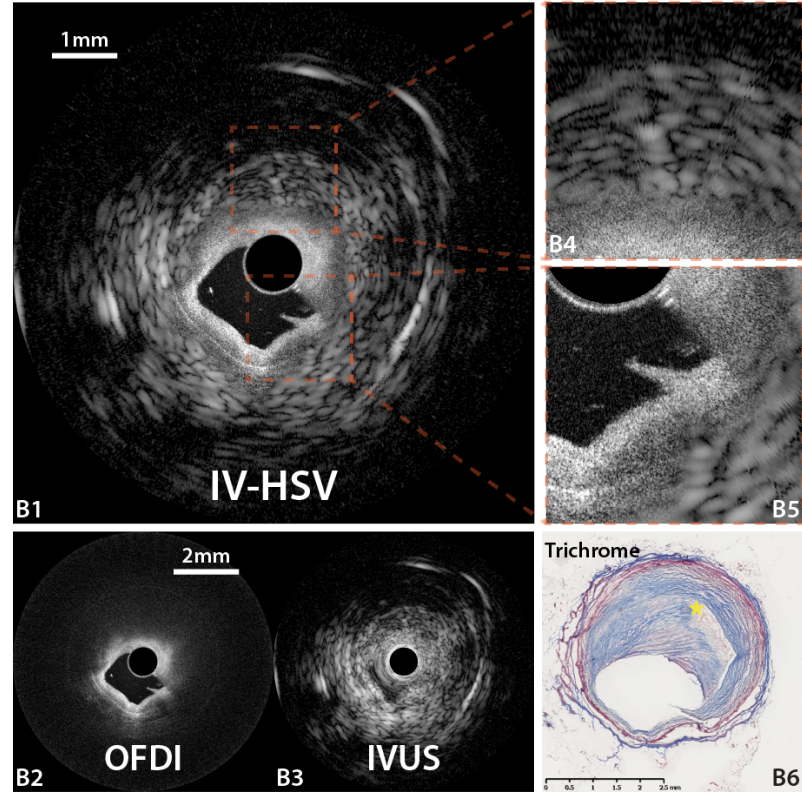

Trichrome

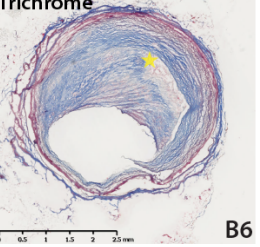


medRxiv preprint doi: https://doi.org/10.1101/2020.06.19.20130302; this version posted June 22, 2020. The copyright holder for this preprint (which was not certified by peer review) is the author/funder, who has granted medRxiv a license to display the preprint in perpetuity.

Figure 3. Representative holistic structural visualization (IV-HSV) of fibroatheromas in human coronary artery ex vivo.

IV-HSV images (A1 and B1), combining the OFDI images (A2 and B2) and IVUS images (A3 and B3). (A4 and B4) Segmentation of various plaque features in the IVHSV images, and isolated visualization of the segmented structures, enabling computation of plaque burden (A5 and B5). (A6 and B6) Matching trichrome-stained histopathology. A2 to A5 share the scale bar in A2, and B2 to B5 share the scale bar in B2. (A1-A5) A dissection of the coronary artery appears from 6 to 8 o'clock. (A1) The IV-HSV image visualizes all relevant details of the dissected vessel wall by optimally merging the IVUS and OFDI appearances. (B1) The IV-HSV image clearly visualizes the lumen and the entire vessel wall, including a side branch and calcification. The yellow stars in A4 and B4 indicate necrotic cores, identified by the IVUS signal and confirmed by histopathology (yellow stars in $\mathbf{A 6}$ and B6, respectively).
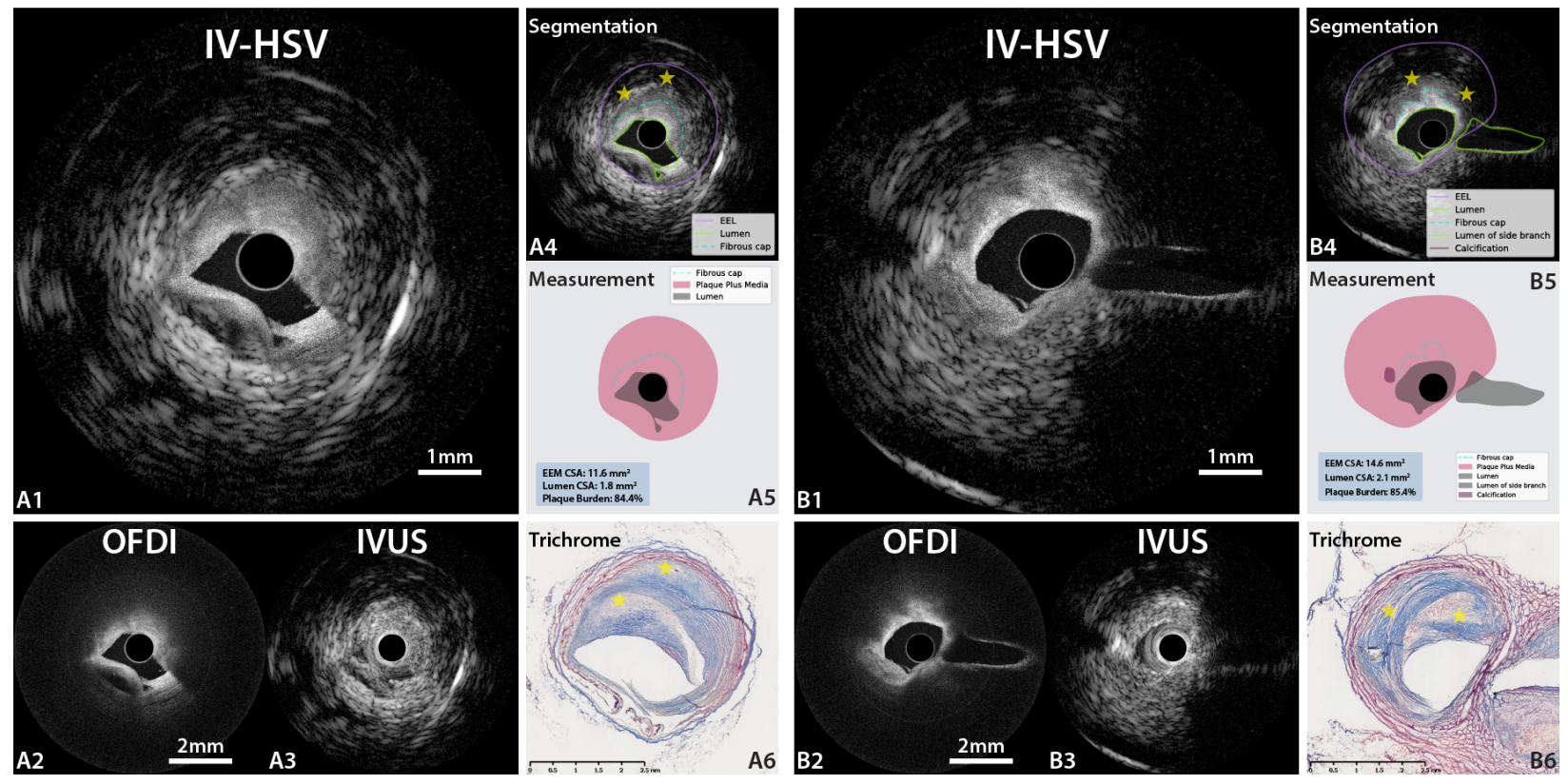
medRxiv preprint doi: https://doi.org/10.1101/2020.06.19.20130302; this version posted June 22, 2020. The copyright holder for this preprint (which was not certified by peer review) is the author/funder, who has granted medRxiv a license to display the preprint in perpetuity.

Figure 4. Representative holistic structural visualization (IV-HSV) of a pathological intimal thickening and a fibro-calcified plaque in human coronary artery ex vivo.

IV-HSV images (A1 and B1), combining the OFDI images (A2 and B2) and IVUS images (A3 and B3). (A4 and B4) Segmentation of various plaque features in the IVHSV images, and isolated visualization of the segmented structures, enabling computation of plaque burden (A5 and B5). Matching histopathology, stained with trichrome (A6), and hematoxylin and eosin (B6), respectively. (A1) The IV-HSV image visualizes the subsurface microstructures and the EEM. (B1) The IV-HSV image reveals the shape of the superficial calcification and the necrotic core as a region with echoattenuation.
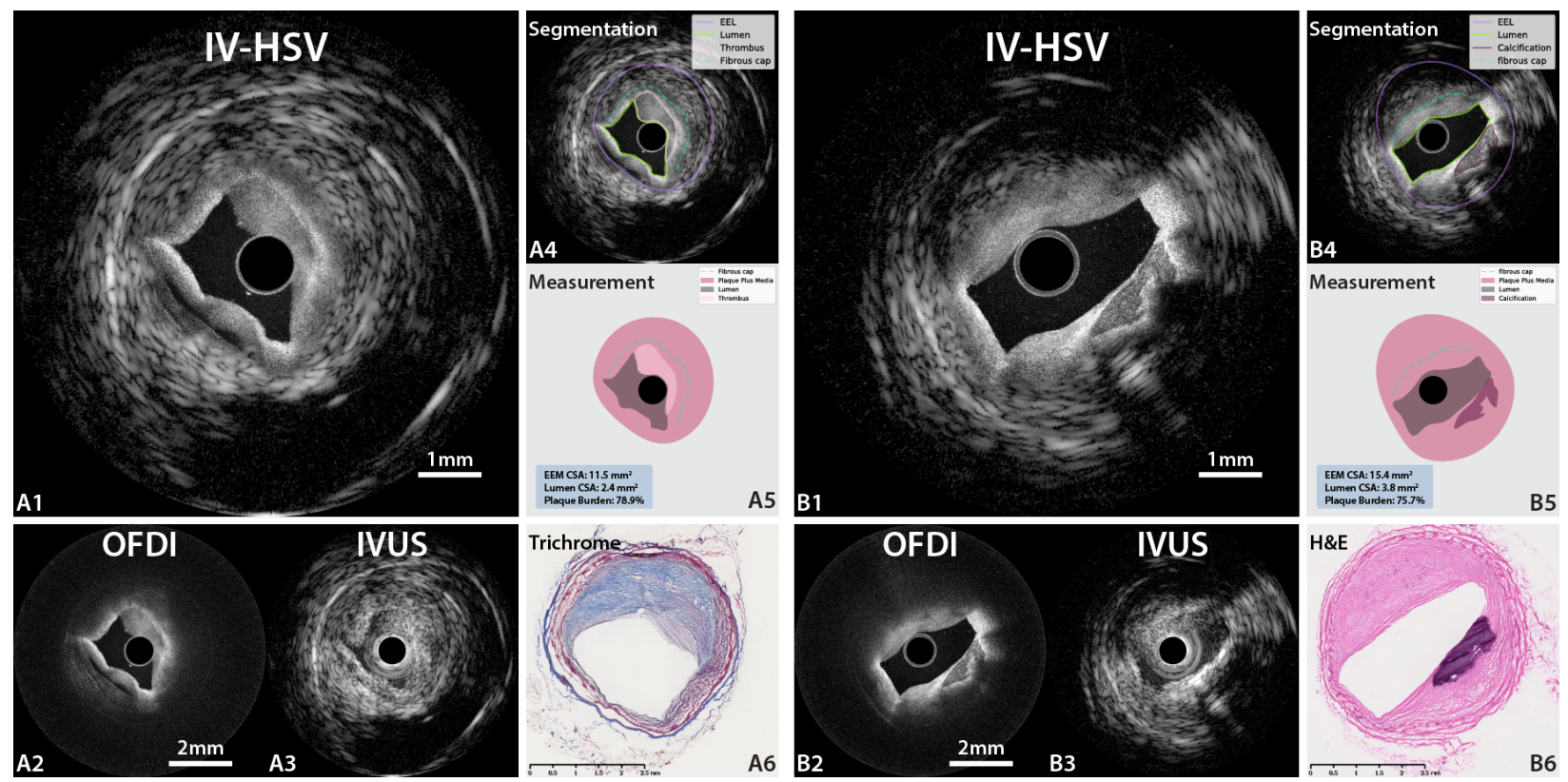
medRxiv preprint doi: https://doi.org/10.1101/2020.06.19.20130302; this version posted June 22, 2020. The copyright holder for this preprint

(which was not certified by peer review) is the author/funder, who has granted medRxiv a license to display the preprint in perpetuity.

All rights reserved. No reuse allowed without permission.

Figure 5. In vivo swine catheterization and intravascular imaging.

(A) Coronary angiogram showing the left coronary arteries during pullback imaging. (B)

Pearson's correlation analysis of luminal CSA measured independently with OFDI and

IVUS. (C) Bland-Altman plot of the luminal CSA measured independently with OFDI and

IVUS. (D, E, and F) and (G, H, and I) are intrinsically co-registered OFDI, IVUS, and IV-

HSV cross-sectional images acquired in the LAD. The yellow stars indicate the locations of side branches. Both (B) and (C) show excellent agreement between measurements with the two modalities, accounting to the accuracy of the intrinsic co-registration of the dual-modality imaging system. The green lines in (D, E, G, and H) are the lumen segmentations. (D-I) share the same scale bar in (B). 

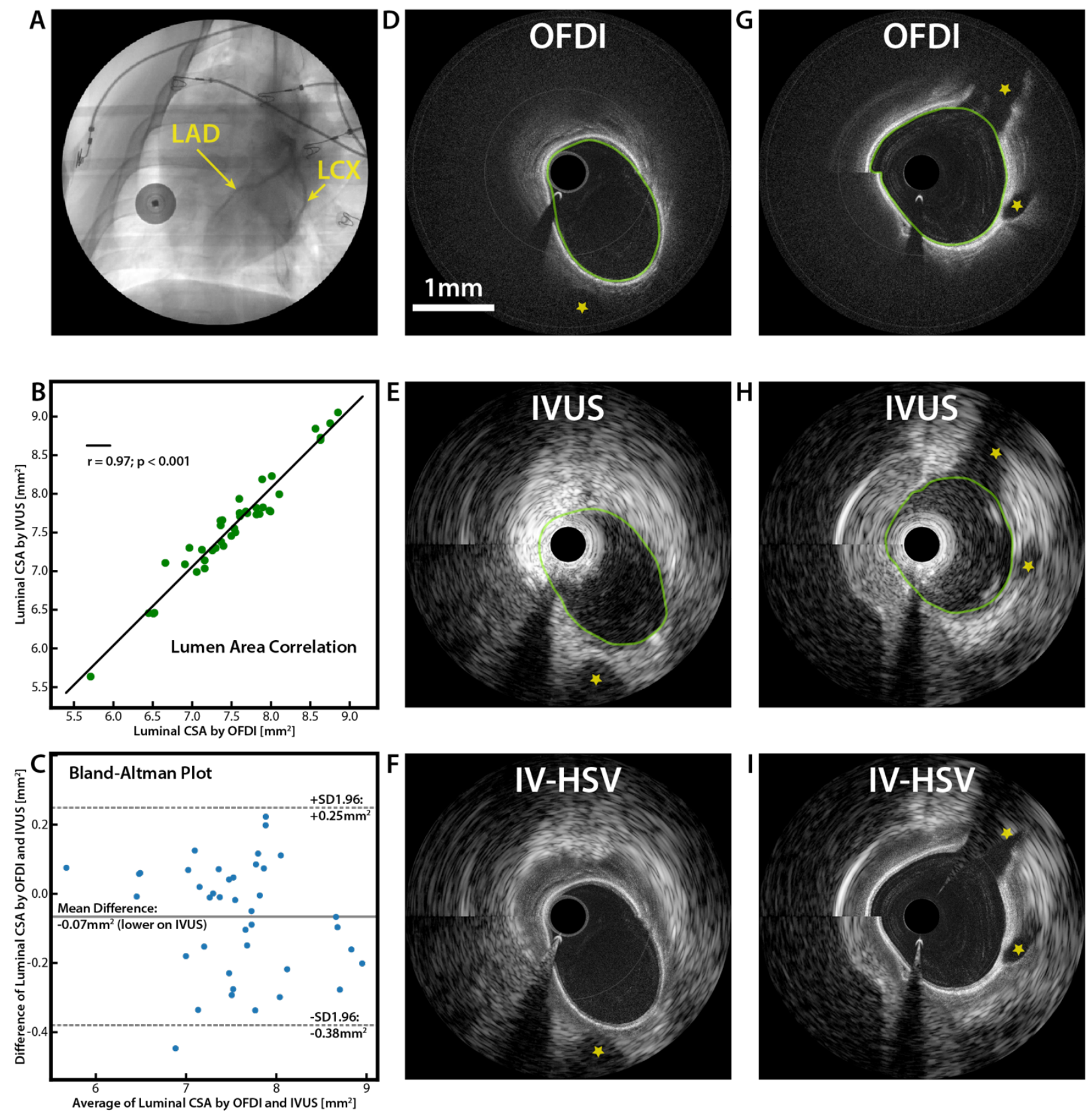
Supplemental Table 1. Comparison of IVUS, OFDI, and the dual-modality IVUS-OFDI in their ability to characterize coronary artery structures

\begin{tabular}{|c|c|c|c|}
\hline & $\begin{array}{c}\text { Grey-scale } \\
\text { IVUS } \\
(40 \mathrm{MHz})\end{array}$ & OCT/OFDI & $\begin{array}{l}\text { Dual-modality } \\
\text { IVUS-OFDI }\end{array}$ \\
\hline Axial resolution & $\sim 200 \mu \mathrm{m}$ & $\sim 15 \mu \mathrm{m}$ & $\sim 15 \mu \mathrm{m}$ \\
\hline Pullback speed & $0.5 \mathrm{~mm} / \mathrm{s}$ & $20-40 \mathrm{~mm} / \mathrm{s}$ & $10-20 \mathrm{~mm} / \mathrm{s}$ \\
\hline $\begin{array}{l}\text { Blood clearing during } \\
\text { pullback }\end{array}$ & Not required & Required & Required for OFDI \\
\hline
\end{tabular}

\section{Visualization of coronary artery structures}

Lumen

EEM

Calcification

Lipid/necrotic core

Fibrous cap

Macrophage accumulation

Cholesterol crystals

Measurements

Lumen area, $\mathrm{mm}^{2}$

Plaque + media area, $\mathrm{mm}^{2}$

Plaque burden, $\%$

Lipid/necrotic core arc, degree

Fibrous cap thickness, $\mu \mathrm{m}$

Calcium thickness, $\mu \mathrm{m}$

Calcium arc, degree $\checkmark \sqrt{ }$

$$
\checkmark \sqrt{ }
$$

$\checkmark \sqrt{ }$

$\checkmark$

NA

NA

NA

$$
\checkmark \checkmark \checkmark
$$

$$
\checkmark \text { (non-lipid-rich }
$$

$$
\text { lesions) }
$$

$\checkmark \checkmark \checkmark \quad \checkmark \checkmark \checkmark$

$\checkmark \sqrt{ }$

$\checkmark \checkmark$

$\checkmark \checkmark$

$\checkmark \checkmark \checkmark$

$\checkmark \checkmark \checkmark$

$\checkmark \checkmark \checkmark$

$\checkmark \checkmark \checkmark$

\section{$\checkmark$}

\section{$\checkmark$}

$\checkmark$




\begin{tabular}{|l|c|c|c|}
\hline Stent expansion & $\checkmark \checkmark$ & $\checkmark \checkmark \checkmark$ & $\checkmark \checkmark \checkmark$ \\
\hline Tissue protrusion & $\checkmark \checkmark$ & $\checkmark \checkmark \checkmark$ & $\checkmark \checkmark \checkmark$ \\
\hline Stent edge dissection & $\checkmark \checkmark$ & $\checkmark \checkmark \checkmark$ & $\checkmark \checkmark \checkmark$ \\
\hline Tissue coverage & $\checkmark$ & $\checkmark \checkmark \checkmark$ & $\checkmark \checkmark \checkmark$ \\
\hline Stent fracture & $\checkmark \checkmark$ & $\checkmark \checkmark$ & $\checkmark \checkmark \checkmark$ \\
\hline Stent malapposition & $\checkmark \checkmark$ & $\checkmark \checkmark \checkmark$ & $\checkmark \checkmark \checkmark$ \\
\hline Neoatherosclerosis & $\checkmark \checkmark$ & $\checkmark \checkmark \checkmark$ & $\checkmark \checkmark \checkmark$ \\
\hline $\begin{array}{l}\text { Underlying plaque } \\
\text { remodeling }\end{array}$ & $\checkmark \checkmark \checkmark$ & $\checkmark$ & \\
\hline
\end{tabular}

NA $=$ not available. $\checkmark=$ feasible, $\checkmark \checkmark=$ good, $\checkmark \checkmark \checkmark=$ very good 